\title{
Relationship Between Marital Adjustment and Infant Attachment in Turkish Fathers
}

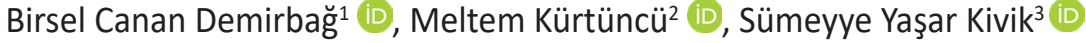 \\ ${ }^{1}$ Karadeniz Technical University, Health Sciences Faculty, Nursing Department, Trabzon, Turkey. \\ ${ }^{2}$ Bulent Ecevit University, Faculty of Health Sciences, Nursing Department, Zonguldak, Turkey. \\ ${ }^{3}$ Obstetrics and Gynecology Hospital, Zonguldak, Turkey.
}

Correspondence Author: Birsel Canan Demirbağ

E-mail: cdemirbag@gmail.com

Received: 22.01 .2019

Accepted: 25.04 .2020

\begin{abstract}
Objective: This study aims to assess the relationship between marital adjustment and paternal-infant attachment.

Methods: This descriptive-cross sectional study was conducted between March and April 2017. No sampling was performed, the study was conducted with 110 fathers who could be accessed between the aforementioned dates and who had babies aged between 0 to 12 months old. Questionnaires were asked fathers by researchers.The outcome measurements: Socio-demographic Information Form, Marital Adjustment Test, and PIAQ. Statistical analysis was performed using SPSS 13.0 program.

Results: Fathers' MAT mean score was found $44.182 \pm 5.17$, and PIAQ mean score was found $77.935 \pm 8.08$. There was a positive, weak, but significant relationship between MAT and PIAQ $(r=0.25 ; p=0.009)$. Marital adjustment scores were found to increase with the increase in "patience", "tolerance", and "pleasure in interaction" subscale scores. MATsubscales were found to affect each other positively, and this effect was found to have a significant relationship with paternal-infant attachment level $(p<0.05)$. Good relationship with the spouse was found have statistically significant relationship with paternal-infant attachment (MWU=165.500; $p=0.000$ ).
\end{abstract}

Conclusion: This study revealed that marital adjustment has effects on paternal-infant attachment.

Keywords: Father, attachment, infant

\section{INTRODUCTION}

New-born attachment is initiated with the sensual connection with the mother, sucking, and seeking. This attachment is formed with the mother's presence next to the infant $(1,2)$. Father, on the other hand, does not experience this attachment as strongly as mother does, but the sensual connection, eye contact and tone of voiceof the father have positive effects on this attachment $(2,3)$. Infant's confidence is improved and the attachment is maintained through establishing close relationships and behaviours among mother, father and infant and being with the infant particularly in stressful situations (2). On the other hand, this attachment becomes stronger after birth, with father's giving his love and embracing his baby by acknowledging his roles as a father $(1,2)$. Fulfilling paternal roles is affected by such factors as father's physical/psychological competence, a positive environment, maintenance of fatherinfant touch, and the nature/adjustment of mother-father relationships $(2,4)$.

A well-adjusted marriageis defined as a marriage in which the couple makes a consensus about an issue related to the family and solves problems by talking and reaching an agreement (5). A well-adjusted marriage both increases quality of life of families and decreases stress in relation to responsibilities $(6,7)$. Deterioration inmarital adjustment due to various reasons causes to either end the marriage or experience continuous domestic stress (8). To decrease stress, couples should regulate their relationship and identify expectations (5). When the adjustment between the couples start to deteriorate, negative effects are observed both in the family and psychological and physical health of the family members (9). Negative relationships between the parents cause weakness in attachment. Maintenance of the attachment between mother and father throughout the marriage also affects the strength of the love between parents and children $(5,9)$. Some studies highlight the positive aspect of establishing mother and father attachment in infant development (4). The literature also involves a number of studies indicating that marital adjustment affects children's psychological health (9). However, given the healthy development of the individual, this can be achieved in a loving warm family environment, so 
the communication of the fathers with their babies should not be ignored (10). In a study; father candidates; reported that they experienced paternal fetal attachment in three areas. These; differentiation of self is listed as acting and giving. In addition, a significant positive relationship was found between paternal fetal attachment in men with strong relationships with their husbands $(11,12)$.

However, studies about therelationship between parentalinfant attachment and marital adjustment is limited in number.Particularly in developing countries like ours, lack of studies about the relationship between paternal-infant attachment and marital adjustment is remarkable. In this regard, the present study aims to raise awareness and draw attention to the issue by analysing the relationship between marital adjustment andpaternal-infant attachment.

\section{METHODS}

This study, which aimed to identify the relationship between paternal-infant attachment and marital adjustment, is descriptive and cross-sectional. Target population of the study was the fathers of 0 to 12 months old babies who were treated in a state hospital which is the established in center of city and the most popular hospital for delivery. The research was conducted between $15^{\text {th }}$ of March and $15^{\text {th }}$ of April, 2017 in Trabzon, Turkey. The hospital which is the largest Women and Child Diseases Hospital of the city where the study was performed, would reflect the characteristics of the country as a whole. No sampling calculation or selection was performed; the study was conducted with fathers who volunteered to participate in the study. The study was conducted in accordance with the Helsinki Declaration. Written informed consent was obtained from each human subjects. In the time interval of the study determined by the researchers total number of 0 to 12 months old infants in the a for mentioned hospital was 160 , and the number of fathers who volunteered to participate in the study was 110 between $15^{\text {th }}$ of March and $15^{\text {th }}$ of April, 2017. Data were collected through the 15-item Socio-demographic Information Form that aimed to collect information about fathers' age and marital status, education level of the parents, family type, health insurance, and baby's gender; MAT (MAT) (15 items), and PIAQ (PIAQ) (19 items) $(2,7)$.

MAT was developed by Locke and Wallace to measure the quality of marriage. This scale is composed of most fundamental and distinguishing questions and was used in various studies in last 30 years as a valid and reliable scale. In Turkey, validity and reliability of the scale was verified by Tutarel-Kıslak in 1999 (13). Scale may be scored between 1 and 60 . The lowest adjustment score is 1 , the highest adjustment score is 60 . The cut-off score for the scale have been assigned as 53 .

PIAQ was improved by Condon et al. in 2008 to evaluate father-infant attachment after birth. The scale consists of 19 articles and three subscales. Each article of the scale has values from 1 to 5 . The lowest score achievable on the scale is 19 , and the highest is 95. A high score shows that attachment is high. In the sixth month, Cronbach's alpha was found to be 0.81 , and in the 12th month, it was 0.78 (14). A Turkish validity and reliability test has been developed, and its Cronbach alpha was found to be 0.76 (2). For this study, Cronbach's alpha was found to be 0.86 .

Data were collected through face-to face interviews conducted by the researchers by visiting the clinics during day shifts and explaining the purpose of the study. Questionnaires were asked fathers by researchers because of using time effectively. Data collection through interviews took about 15 to 20 minutes.

Demographic features of the fathers were described using frequencies, means, and standard deviation tests in SPSS statistical package programming. The data were tested for suitability for normal distribution by histogram and OneSample Kolmogorov Smirnov Test. Comparison of the fathers' demographic features and scale scores were identified using Kruskal Wallis and Mann Whitney $U$ tests. The relationship between the scales were identified using Spearman Correlation analysis. 95\% confidence interval and $p<0.05$ significance level were used for the evaluation of the results.

Prior to data collection, ethical approval was obtained from the hospital where the study was conducted (04.03.2017, Number:201). Participation was on voluntary basis, and the fathers' verbal consent was obtained for data collection. That the study data were based on self-reporting is an important limitation in the research.

\section{RESULTS}

This section demonstrates findings obtained from the analysis of the data collected from the fathers through the scales used as data collection tools.The mean age of fathers was found between 20-49 years, (Mean: $33.79 \pm$ 5.72; Min:20; Max:45; Median:). $52.7 \%$ of the fathers had high school degree; $54.5 \%$ was worker; $53.6 \%$ had middle income level; $84.5 \%$ of father had social security; $39.1 \%$ of father had 1 to 5 years marriage; $30 \%$ of father didn't have child before; $63.6 \%$ of babies was a girl; $\% 67.3$ ofwife were housewife. The fathers' MAT mean score was found $44.182 \pm 5,174$ (Mean: 44.182 \pm 5.174; Min: 30, Max: 57; Median: 44), and PIAQ mean score was $77.935 \pm 8,080$ (Mean: $77.93 \pm 0.77$; Min: 48.5, Max:92.6; Median:78.44). As to the mean scores according to subscales, they were found $33.083 \pm 3.740$ for "patience and tolerance", 26,388 $\pm 3,712$ for "pleasure in interaction", and $18.464 \pm 1.974$ for "affection and pride" (Table 1). Correlation analysis was conducted in order to find out the relationship between paternal-infant attachment total score and "patience and tolerance" subscale; result showed that there was a $91.3 \%$ positive, significant relationship between the scores $(r=0.913 ; p=0.000<0.05)$. Accordingly, "patience and tolerance" subscale score increasesasthe paternalinfant attachment total score increases. 
Table 1. MAT and PIAQ means

\begin{tabular}{|l|c|c|c|c|c|c|}
\hline $\begin{array}{l}\text { Marital } \\
\text { Adjustment }\end{array}$ & 110 & 44.00 & 44.182 & 5.174 & 30.000 & 57.000 \\
\hline $\begin{array}{l}\text { Patience and } \\
\text { Tolerance } \\
\text { Subscale }\end{array}$ & 110 & 33.40 & 33.083 & 3.740 & 21.100 & 40.000 \\
\hline $\begin{array}{l}\text { Pleasure in } \\
\text { Interaction } \\
\text { Subscale }\end{array}$ & 110 & 26.75 & 26.388 & 3.712 & 13.000 & 34.000 \\
\hline $\begin{array}{l}\text { Affection } \\
\text { and Pride } \\
\text { Subscale }\end{array}$ & 110 & 19.00 & 18.464 & 1.974 & 8.300 & 20.000 \\
\hline PIAQ & 110 & 78.45 & 77.935 & 8.080 & 48.500 & 92.600 \\
\hline
\end{tabular}

Kruskal Wallis $\mathrm{H}$-Test was performed in order to identify whether MAT and PIAQ subscale mean scores demonstrated any significant differences in terms of the definition of fatherhood variable; significant differenceswere detected in all subscale mean scores. Mann Whitney $U$ test was performed for the identification of the group that created the difference (Table 2).

Correlation analysis was conducted in order to find out the relationship between paternal-infant attachment total score and "pleasure in interaction" subscale; results indicated a $85.7 \%$ positive, significant relationship between the scores $(r=0.857 ; p=0.000<0.05)$.

Table 2. MAT and PIAQ scores according to definitions of fatherhood

\begin{tabular}{|c|c|c|c|c|}
\hline & & Mean Rank & Median (Min-Max) & $\begin{array}{c}\text { Test scores } \\
\text { KW } \\
\text { p }\end{array}$ \\
\hline \multirow[t]{5}{*}{$\begin{array}{l}\text { Marital } \\
\text { Adjustment }\end{array}$} & & 44.10 & $78.451(48.50-92.60)$ & \multirow{5}{*}{$\begin{array}{l}\mathrm{KW}: 6.278 \\
\mathrm{p}: 0.959\end{array}$} \\
\hline & $\begin{array}{l}\text { I am not ready to become a father, therefore I cannot support } \\
\text { my wife }\end{array}$ & 33.00 & 34.000 & \\
\hline & $\begin{array}{l}\text { I am not ready to become a father, I support my wife about the } \\
\text { baby care }\end{array}$ & 41.81 & 42.211 & \\
\hline & I take care of my baby willingly, I support my wife about this & 45.40 & 44.031 & \\
\hline & $\begin{array}{l}\text { I am always ready for fatherhood, but I cannot help my wife } \\
\text { much because of my job }\end{array}$ & 43.68 & 42.813 & \\
\hline \multirow[t]{4}{*}{$\begin{array}{l}\text { Patience and } \\
\text { Tolerance Subscale }\end{array}$} & $\begin{array}{l}\text { I am not ready to become a father, therefore I cannot support } \\
\text { my wife }\end{array}$ & 27.20 & 27.303 & \multirow{4}{*}{$\begin{array}{r}\mathrm{KW}: 20.875 \\
\text { p: } \mathbf{0 . 0 0 1}\end{array}$} \\
\hline & $\begin{array}{l}\text { I am not ready to become a father, I support my wife about the } \\
\text { baby care }\end{array}$ & 30.88 & 30.123 & \\
\hline & I take care of my baby willingly, I support my wife about this & 34.77 & 34.876 & \\
\hline & $\begin{array}{l}\text { I am always ready for fatherhood, but I cannot help my wife } \\
\text { much because of my job }\end{array}$ & 31.94 & 31.329 & \\
\hline \multirow{4}{*}{$\begin{array}{l}\text { Pleasure in } \\
\text { Interaction } \\
\text { Subscale }\end{array}$} & $\begin{array}{l}\text { I am not ready to become a father, therefore I cannot support } \\
\text { my wife }\end{array}$ & 13.00 & 13.014 & \multirow{4}{*}{$\begin{array}{r}\mathrm{KW}: 14.443 \\
\text { p: } \mathbf{0 . 0 0 2}\end{array}$} \\
\hline & $\begin{array}{l}\text { I am not ready to become a father, I support my wife about the } \\
\text { baby care }\end{array}$ & 25.10 & 25.823 & \\
\hline & I take care of my baby willingly, I support my wife about this & 27.56 & 27.874 & \\
\hline & $\begin{array}{l}\text { I am always ready for fatherhood, but I cannot help my wife } \\
\text { much because of my job }\end{array}$ & 25.73 & 26.001 & \\
\hline \multirow[t]{4}{*}{$\begin{array}{l}\text { Affection and Pride } \\
\text { Subscale }\end{array}$} & $\begin{array}{l}\text { I am not ready to become a father, therefore I cannot support } \\
\text { my wife }\end{array}$ & 8.30 & 8.302 & \multirow{4}{*}{$\begin{array}{r}\mathrm{KW}: 11.113 \\
\text { p: } 0.011\end{array}$} \\
\hline & $\begin{array}{l}\text { I am not ready to become a father, I support my wife about the } \\
\text { baby care }\end{array}$ & 17.01 & 17.001 & \\
\hline & I take care of my baby willingly, I support my wife about this & 18.91 & 18.231 & \\
\hline & $\begin{array}{l}\text { I am always ready for fatherhood, but I cannot help my wife } \\
\text { much because of my job }\end{array}$ & 18.54 & 18.320 & \\
\hline \multirow[t]{5}{*}{ PIAQ } & & 27.00 & $44.00(30-57)$ & \multirow{5}{*}{$\begin{array}{r}\mathrm{KW}: 22.672 \\
\text { p: } \mathbf{0 . 0 0 1}\end{array}$} \\
\hline & $\begin{array}{l}\text { I am not ready to become a father, therefore I cannot support } \\
\text { my wife }\end{array}$ & 48.50 & 48.632 & \\
\hline & $\begin{array}{l}\text { I am not ready to become a father, I support my wife about the } \\
\text { baby care }\end{array}$ & 73.00 & 74.021 & \\
\hline & I take care of my baby willingly, I support my wife about this & 81.25 & 82.342 & \\
\hline & $\begin{array}{l}\text { I am always ready for fatherhood, but I cannot help my wife } \\
\text { much because of my job }\end{array}$ & 76.22 & 77.013 & \\
\hline
\end{tabular}


Hence, "pleasure in interaction" subscale score increases as paternal-infant attachment total score increases. Correlation analysis was conducted in order to find out the relationship between paternal-infant attachment total score and "affection and pride" subscale; results indicated a $64.7 \%$ positive, significant relationship between the scores $(r=0.647 ; p=0.000<0.05)$. Hence, "affection and pride" subscale score increases as the paternal-infant attachment total score increases. As a result of the correlation analysis conducted to determine the relationship between the fatherbaby attachment scale total and marital adjustment, a $25.0 \%$ positive relationship was found between the scores $(r=0.250$; $p=0.009<0.05)$. Accordingly, as the total score of the fatherbaby attachment scale increases, the marital adjustment score also increases (Table 3)

While the correlation analysis between patience and tolerance subscale $(r=0.232 ; p=0.015<0.05)$, interaction interaction subscale $(r=0.223 ; p=0.012<0.05)$ and marital adjustment were positively significant, There was no significant relationship between love and pride subscale ( $r=0.121 ; p=0.209>0.05)$ and marital adjustment. (Table 3).

Table 3. The relationship between the MATand PIAQ scores

\begin{tabular}{|c|c|c|c|c|c|c|}
\hline & & $\begin{array}{c}\text { Marital } \\
\text { Adjustment }\end{array}$ & $\begin{array}{l}\text { Patience } \\
\text { and } \\
\text { Tolerance } \\
\text { Subscale }\end{array}$ & $\begin{array}{c}\text { Pleasure in } \\
\text { Interaction } \\
\text { Subscale }\end{array}$ & $\begin{array}{l}\text { Affection } \\
\text { and } \\
\text { Pride } \\
\text { Subscale }\end{array}$ & PIAQ \\
\hline \multirow{2}{*}{$\begin{array}{l}\text { Marital } \\
\text { Adjustment }\end{array}$} & $r$ & 1,000 & 0,232 & 0,238 & 0,121 & 0,250 \\
\hline & $p$ & 0,000 & 0,015 & 0,012 & 0,209 & 0,009 \\
\hline \multirow{2}{*}{$\begin{array}{l}\text { Patience } \\
\text { and } \\
\text { Tolerance } \\
\text { Subscale }\end{array}$} & $r$ & 0,232 & 1,000 & 0,672 & 0,455 & 0,913 \\
\hline & $p$ & 0,015 & 0,000 & 0,000 & 0,000 & 0,000 \\
\hline \multirow{2}{*}{$\begin{array}{l}\text { Pleasure in } \\
\text { Interaction } \\
\text { Subscale }\end{array}$} & $r$ & 0,238 & 0,672 & 1,000 & 0,429 & 0,857 \\
\hline & $p$ & 0,012 & 0, & 0,000 & 0,000 & 0,000 \\
\hline \multirow{2}{*}{$\begin{array}{l}\text { Affection } \\
\text { and Pride } \\
\text { Subscale }\end{array}$} & $r$ & 0,121 & 0,455 & 0,429 & 1,000 & 0,647 \\
\hline & $p$ & 0,209 & 0,000 & 0,000 & 0,000 & 0,000 \\
\hline \multirow[t]{2}{*}{ PIAQ } & $r$ & 0,250 & 0,913 & 0,857 & 0,647 & 1,000 \\
\hline & $p$ & 0,009 & 0,000 & 0,000 & 0,000 & 0,000 \\
\hline
\end{tabular}

Comparison of father's demographic characteristics between MAT and PIAQT of total scores, we didn't find any statistically significant difference family type, health insurance, and baby's gender. Comparison of fathers' MAT total mean scores with the relationship with the spouse indicated statistically significant difference (Mann Whitney $U=165.500 ; p<0,0001$ ). Fathers who reportedly had good relationships with their

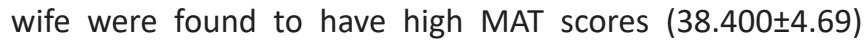
(Table 4). Comparison of fathers' total MAT mean scores with duration of marriage variable indicated significant differences between the group mean scores ( $K W=8.128$; $p<0.05$ ) (Table 4). Comparison of fathers' education level and PIAQ total scores revealed statistically significant differences ( $K W=10.832 ; p<0.05)$. Mann Whitney $U$ test results revealed that this difference resulted from the fact that university scores (Mean $=81.300 \pm 6.432$ ) were higher than secondary (Mean=75.863 \pm 6.702 ) and primary (Mean=74.729 \pm 6.819 ) school scores (Table 4).

Table 4. Analysis of MAT and PIAQ scores according to relationships with the spouse, education, and marriage duration

\begin{tabular}{|c|c|c|c|c|}
\hline Characteristics & $\begin{array}{c}\text { MAT } \\
\text { Mean Rank } \\
\text { (Min-Max) }\end{array}$ & $\begin{array}{c}\text { Test scores } \\
\text { MWU } \\
\text { p }\end{array}$ & $\begin{array}{c}\text { PAQT } \\
\text { Mean Rank } \\
\text { (Min-Max) }\end{array}$ & $\begin{array}{c}\text { Test } \\
\text { scores } \\
\text { MWU } \\
p\end{array}$ \\
\hline \multicolumn{5}{|l|}{$\begin{array}{l}\text { Relationships } \\
\text { with the } \\
\text { spouse }\end{array}$} \\
\hline Good & $\begin{array}{l}44.231 \\
(43.081- \\
49.634) \\
\end{array}$ & \multirow[t]{2}{*}{$\begin{array}{c}\text { MWU: } 165.500 \\
\text { p: } 0.001\end{array}$} & $\begin{array}{c}79.654 \\
(78.987-86.388)\end{array}$ & \multirow[t]{2}{*}{$\begin{array}{l}\text { MWU: } \\
318.000 \\
\text { p: } 0.058\end{array}$} \\
\hline Medium & $\begin{array}{l}38.934 \\
(39.01- \\
43.095)\end{array}$ & & $\begin{array}{c}74.080 \\
(73.989-81.435)\end{array}$ & \\
\hline \multicolumn{5}{|l|}{$\begin{array}{l}\text { Marriage } \\
\text { Duration }\end{array}$} \\
\hline 1 to 5 years & $\begin{array}{l}45.765 \\
(45.00- \\
50.773) \\
\end{array}$ & \multirow[t]{3}{*}{$\begin{array}{c}\text { MWU : } 8.128 \\
\text { p: } 0.017\end{array}$} & $\begin{array}{c}79.982 \\
(79.054-87.003)\end{array}$ & \multirow[t]{3}{*}{$\begin{array}{c}\text { MWU: } \\
2.439 \\
\text { p: } 0.295\end{array}$} \\
\hline 6 to 10 years & $\begin{array}{l}44.987 \\
(45.010- \\
48.728)\end{array}$ & & $\begin{array}{c}78.185 \\
(78.000-87.207)\end{array}$ & \\
\hline $\begin{array}{l}11 \text { years and } \\
\text { more }\end{array}$ & $\begin{array}{l}42.540 \\
(43.000- \\
47.342)\end{array}$ & & $\begin{array}{c}77.430 \\
(76.980-82.015)\end{array}$ & \\
\hline \multicolumn{5}{|l|}{$\begin{array}{l}\text { Education } \\
\text { Level }\end{array}$} \\
\hline Primary school & $\begin{array}{l}40.239 \\
(39.289- \\
47.357) \\
\end{array}$ & \multirow[t]{4}{*}{$\begin{array}{l}\text { MWU: } 4.045 \\
\text { p: } 0.257\end{array}$} & $\begin{array}{c}75.980 \\
(75.100-81.548)\end{array}$ & \multirow[t]{4}{*}{$\begin{array}{c}\text { MWU : } \\
10.832 \\
\text { p: } \mathbf{0 . 0 1 3}\end{array}$} \\
\hline $\begin{array}{l}\text { Secondary } \\
\text { School }\end{array}$ & $\begin{array}{l}43.875 \\
(42.987- \\
47.678)\end{array}$ & & $\begin{array}{c}76.962 \\
(76.324-82.565)\end{array}$ & \\
\hline High school & $\begin{array}{l}44.687 \\
(44.001- \\
49.770) \\
\end{array}$ & & $\begin{array}{c}78.094 \\
(77.985-86.411)\end{array}$ & \\
\hline University & \begin{tabular}{|l|}
44.672 \\
$(44.027-$ \\
$49.585)$ \\
\end{tabular} & & $\begin{array}{c}82.500 \\
(81.989-87.730)\end{array}$ & \\
\hline
\end{tabular}

According to the results of Kruskal Wallis $\mathrm{H}$-Test conducted to determine whether the mean scores of the marital adjustment scores of the fathers participating in the study show a significant difference in terms of the marriage duration variable; The difference between group averages was found to be significant ( $K W=8.128 ; p=0.017<0.05)$. Mann Whitney $\mathrm{U}$ test was used to determine which group the difference originated from. According to this, fathers' marriage compliance scores (Mean=45.861 \pm 4.912 ) with a marriage duration of 1-5 years were higher than those of fathers with a marriage duration of $6-10$ years $(43.585 \pm 5.143)$. (45.861 \pm 4.912), fathers with a marriage period of 11 years and over 
were found to be higher than the marriage compliance scores $(42.346 \pm 4.996)$.

\section{DISCUSSION}

Attachment is a concept that has an important place in the human development process $(2,4)$. Theoreticians who developed the infant attachment concept state that a reliable infant-parent attachment is created as a result of infant's sending signals for his needs and the caregiver adult's giving appropriate response to these needs $(4,5)$. Attachment can be improved as long as the parents continue their positive communication behaviours with the children. High attachment scores in this study indicate fathers' positive relationships with their children.

Marital adjustment is acknowledged as one of the most important factors that affect the attachment process $(3,5,7)$. While any adjustment disorders weaken the relationship between parents, it could also affect the relationship between the father and the infant, whose need for care from a mother is a must particularly in the first years $(15,16)$. Of the present study which can promote development of secure infantparent attachment relationships in the next generation. This study found that although there was astatistically significant relationship between paternal-infant attachment and a well-adjusted marriage, this relationship was a weak one. However, correlation analysis which aimed to identify the relationship between paternal-infant attachment total score and marital adjustment revealed $25,0 \%$ positive, significant relationship between the scores. Hence, marital adjustment score increases as the paternal-infant attachment total score increases.

Marital adjustment starts with healthy foundations formed by the parents whodecidedto share life together; and it continues throughout their life with right communication in the family, decision for pregnancy, pregnancy process, and birth and afterbirth relationships $(5,17)$. Marital adjustment is couples' solving problems and sharing their happiness at every stage of marriage by talking $(5,16,18)$. Findings of this study indicate that maritaladjustment is at good level and "tolerance" subscale is significantly associated with paternalinfant attachment level, which is line with the related literature.

Mercer states that maternal attachment starts naturally during the pregnancy period and highlights the importance of birth and afterbirth for the maintenance of this case (18). It is known that paternal attachment could be strengthened by starting this relationship - which starts between mother and infantduring pregnancy - for paternal-infant attachment during pregnancy and maintaining it after birth and in the first years of the baby (18-20). Significant relationships were detected between "pleasure in interaction in marriage", "affection and pride", "patience and tolerance" and infant attachment scale, which indicates positive relationships between the parents.
A number of studies have revealed that prospective fathers who follow the pregnancy process with their wives start to accept paternity roles by allocating sufficient time to their wife and babies after birth, taking care of the baby, and loving her (17-20). Studies report that patience, tolerance, pleasure, affection and pride have effects on attachment behaviours and maintenance of a well-adjusted marriage $(5,15)$. This study indicates that fathers' definition of fatherhood had significant relationships with marital adjustment, marital adjustment subscales and PIAQ. This finding shows that marital adjustment is an effective factor in infant attachment.

Mutual understanding, cooperation, love, and respect are some of the things expected from a healthy marriage. The literature indicates that these concepts which have effects on marriage also affect maintenance of positive marriageas well as the relationships between children and other family members $(18,19)$. The current study found no significant relationships between paternal-infant attachment and the factors affecting parental attachments reported in the literature (e.g. planned pregnancy, gender expectation, and number of children). However, marital adjustment subscales such as "patience and tolerance", "pleasure in interaction", and "affection and pride"were found to have important relationships with paternal-infant attachment.

A number of studies report that education level has also effects on the development of attachment $(4,15)$. The present study found that the relationship between marital adjustment subscales of "patience and tolerance" and the father's education level have positive effects on paternalinfant attachment. Paternal-infant attachment increases with the increase in education level. Presence of the relationship between the increase in parents' education level and attachment is in line with the literature. Marriage is a process which has ups and downs between the couples $(20,21)$. Living together/doing things together and behaviour styles could also be defined as adjustment by couples. Adjustmentis affected by factors such as spousal relationships, marriage duration, education, understanding, and respect (7). This study found a significant relationship between marital adjustment subscales of "patience and tolerance" and fathers' education and paternal-infant attachment. Paternalinfant attachment levelwas found to increase with the increase in the education level. The literature also has parallel information about the presence of the relationship between the increase in education level and attachment $(4,5)$. The present study did not found relationship between marital adjustment and age, salary, health insurance, familt type and sex of child.

Length of marriage duration affects marital adjustment $(3,18,22)$. This study found that fathers with longer marriage durations demonstrate higher paternal-infant attachment levels. Besides, relationships with the spouse were found to affect the infant attachment level significantly, and paternal attachment levels were found to increase with the increase in adjustment between the couples. The literature mentions the effect of mother and father relationships on infant 
attachment level $(23,24)$. Importance of spousal relationship in marital adjustment has been supported with this study as well.

\section{Limitations}

There is a limitation of the current study. Participants were included in a non-randomized design, and only $68.7 \%$ of the target sample size was reached. Our inability to reach the targeted number in the sample might have increased the likelihood of type I errors. Therefore, our results cannot be generalized to the entire population.

\section{CONCLUSION}

This study found a significant relationship between marital adjustment andpaternal-infant attachment. Besides, there was a significant relationship between paternal-infant attachment and marital adjustmentsubscales of patience, pleasure and affection. Significant relationships were also found between marriage duration, fathers'education level, and spousal relationships and paternal-infant attachment and marital adjustment.

\section{REFERENCES}

[1] Shieh C, Kravitz M, Wang HH. What do we know about maternal-fetal attachment? J Med Sci 2001; 17: 448-445.

[2] Güleç D, Kavlak O. The study of reliability and validity of paternal-infant attachment scale in Turkish society. JHS 2013; 10(2): 170-181.

[3] Morsünbül Ü, Çok F. Attachmentand related variables. Current Approaches in Psychiatry, 2011; 3(3): 553-570.

[4] Newland LA, Coyl DD, Chen HH. Fathering and attachment in the USA and Taiwan: contextual predictors and child outcomes. Early Child Dev Care 2010; 180(1): 173-191.

[5] Marchand JF. Husbands' an wives' maritalquality: The role of adult attachment orientations, depressive symptoms, and conflict resolution behaviors. Attach Hum Dev 2005; 6(1): 99112.

[6] Condon TJ, Corkindale C. The correlates of antenatal attachment in pregnant women. Br J Clin Psychol 1997; 70(4): 359-372.

[7] Monin JK, Feeney BC, Schulz R. Attachment orientation and reactions to anxiety expression in close relationships. Pers Relatsh 2012; 19(3): $535-550$.
[8] Yılmaz SD, Beji NK. Therelationship between anxiety and depression level and coping styles with stress of pregnant women. Genel Tip Dergisi 2010; 20(3): 99-108.

[9] Kelly RJ, Marks BT, El-Sheikh M. Longitudinal relations between parent-child conflict and children's adjustment: The role of children'ssleep. J Abnorm Child Psychol 2014; 42(7): 11751185.

[10] Dizman H, Gürsoy F. Aggression tendencies of children with and without mother who attend the fourth and fifth grades of primary education. Kastamonu Eğitim Dergisi 2005; 13(2): $437-446$

[11] Başal AH. Turkey's prenatal, birth and postpartum traditions related to child development and education, customs and beliefs. Eğitim Fakültesi Dergisi 2006; XIX(1): 45-70.

[12] Cranley SM. Roots of Attachments: The relationship of parets with their unborn. Birth 1981; 17(6): 59-83.

[13] Kişlak-Tutarel Ş. Validity and reliability study on marital adjustment scale (MAS). 3P Dergisi 1999; 7(1): 54-56.

[14] Üstünoz A, Güvenç G, Akyüz A, Oflaz F. Comparison of maternal-andpaternal-fetal attachment in Turkish couples. Midwifery 2010; 26 (2): 1-9.

[15] Marchand JF. Husbands' an wives' maritalquality: The role of adult attachment orientations, depressive symptoms, and conflict resolution behaviors. Attach Hum Dev 2005; 6(1): 99112.

[16] Tüzün O, Sayar K. Attachment the oryand psychopathology. Dusunen Adam The Journal of Psychiatry and Neurological Sciences 2006; 19: 24-39.

[17] Erbek E, Beştepe E, Akar H, Eradamlar N, Alpkan RL. Marital adjustment. Dusunen Adam The Journal of Psychiatry and Neurological Sciences 2005; 18 (1): 39-47.

[18] Mercer RT. Becoming a mother versus maternal role attainment. J Nurs Scholarsh 2004; 36(3): 226-232.

[19] Lindgren K. Relationships among maternal-fetal attachment, prenatal depression, and health practices in pregnancy. Res Nurs Health 2001; 24: 203-217.

[20] Soysal AŞ, Bodur Ş, İşeri E, Şenol S. Attachment process in infancy: A review. J Clin Psychiat 2005; 8: 88-99.

[21] Şener T, Terzioğlu G. Investigation between some socioeconomic, demographic variables and effect of communication on marital adjustment. Family and Society 2008; 4(13): 7-20.

[22] Greeff AP, Malherbe HL. Intimacy and marital satisfaction in spouses. J Sex Marital Ther 2001; 27: 247-257.

[23] Okanlı A, Tortumluoğlu G, Kırpınar i. Determining postpartum social support needs of mothers and the support they received. Anatolian Journal of Psychiatry 2003; 4(2): 98-105.

How to cite this article: Demirbağ BC, Kürtüncü M, Kivik SY. Relationship Between Marital Adjustment and Infant Attachment in Turkish Fathers. Clin Exp Health Sci 2020; 10: 125-130. DOI: 10.33808/clinexphealthsci.516309 